\title{
Implementation of an integrated management system into a small building company
}

\section{Implantación de un sistema integrado de gestión en una constructora de tamaño pequeño}

\author{
Humberto Giacomello (Main Author) \\ Construbel Construções Ltda., Brasil \\ giacomello@terra.com.br
}

Marcos Aurelio Gonzalez Stumpf (Contact Author)

Unisinos, PPGEC/MPArqUrb, Brasil

MGONZALEZ@UNISINOS.BR

5551.35901122 ext $1663 / 5551.35908172$

Av. Unisinos, 950 - 6B308 - São Leopoldo, RS, Brasil - 93022-000

\section{Resumen}

Las empresas de construcción suelen adoptar nuevas herramientas y prácticas de gestión a fin de obtener un mayor nivel de calidad. La integración entre la gestión de la producción y otros sistemas de gestión es importante para el logro de mejoras en la construcción. Sin embargo, en algunos casos, las empresas utilizan estos sistemas de manera aislada y además hay pocos estudios que describen aplicaciones de sistemas integrados en pequeñas empresas de construcción, las cuales constituyen la mayoría de las empresas del sector en Brasil. En este trabajo se presenta la implantación de un sistema integrado de gestión en una empresa de construcción pequeña. El trabajo incluye el diagnóstico de la gestión en esta empresa, la proposición y aplicación de un proceso integrado, así como el análisis de los resultados. El estudio fue desarrollado a través de la observación de tres obras en la ciudad de Bento Gonçalves, Brasil. Se implementaron herramientas de gestión en corto, mediano y largo plazos. Con los resultados obtenidos, se puede concluir que hay posibilidad de adoptar este sistema en las empresas pequeñas, con una reducción de las pérdidas en el proceso de producción.

Palabras clave: Construcción civil, sistema de gestión integrado, reducción de pérdidas.

\section{Introduction}

Management systems have an important role in reducing the losses in the construction sector. It can be seen an increase in the development and use of management systems, mainly through certification programs such as ISO 9001 and the Brazilian Program of Quality and Productivity at Habitat (PBQP-H), as a way of ensuring standardization and thus reducing costs and waste generation (ABNT, 2008, Brazil, 1998).

However, despite some improvements in applying certifications, construction companies are facing difficulties in implementing such systems. Often processes, training and indicators are not applied effectively in site works. In other cases the certification sought by companies is related only to marketing and company image (Sukster, 2005).
Andrea Parisi Kern

Unisinos, PPGEC, Brasil

apkern@unisinos.br

Manuscript Code: 0542

Date of reception/acceptation: 15oct2014/01dec2014

\section{Abstract}

Building firms has implanted tools and practices to improve their quality level. The integration between production and other management system is beneficial for achieving improvements in construction. However, in some cases, construction companies develop isolated management systems, and there are few research papers that describe this kind of application in small construction companies, which constitute the majority of building companies in Brazil. This paper presents the implantation of an integrated management system in a small construction company. The work includes the diagnosis of management system of the company, the proposition and applying of an integrated process, and the identification of outcomes. It was developed through observation of three building sites in Bento Gonçalves, a city on southern Brazil. On research process it were implanted tools on planning and control to management systems to short, medium, and large terms. After all, our results may conclude that there is viability to implant this system in small building companies, with waste reduction on the production process.

Keywords: Civil construction, integrated management systems, waste reduction.

The lack of formal management systems is a reality for most construction companies, with the exception of quality systems, which are increasingly used in recent years in Brazil (Abreu et al. 2008; Maekawa et al., 2013; Neiva Neto et al, 2013).

In this context, this paper presents a study about the integration of the production planning and control of process (PPCP) with the other management systems in a construction company, including management systems for quality, environment and occupational health and safety. More specifically, the aim of this paper is to propose, implement and verify the results of an integrated management system (IMS) in a small construction company in Bento Gonçalves, in southern Brazil. 


\section{Integration of Different Aspects in the Management System}

Structuring a quality system can be directly linked to several existing features in a system of planning and control of production (Soares, 2003). The integration between the PPCP and the quality management system is important to be improvements in the site works, but it is essential the participation of all employees involved in the actions of planning, implementation and monitoring of activities (Sukster, 2005).

In addition to quality management system (QMS), which is somewhat common in Brazilian construction sector, attention should be given to the management system of occupational health and safety (OHSMS), which is often overlooked by companies especially to small and medium construction enterprises.

Santos et al. (2013) present a study characterizing the situation of small and medium enterprises (SMEs) in Portugal. The method used to evaluate the implemented system was in the form of questionnaires. In the questionnaire, the main reasons for SMEs indicated to opt for certification was to eliminate or minimize risks to workers while the main reason for not certify was implementing costs. The main benefits that the Portuguese SMEs have obtained from certifications have been improving working conditions - ensuring compliance with the law - and better internal communication of occupational hazards. The main difficulties in achieving an OHSAS certification are also presented including the high cost of certification, difficulties to motivate the staff, difficulties in changing the culture of the company and increased bureaucracy.

Another important aspect is the environmental management system (EMS), let alone by business, probably because it is a matter of more recent interest, because there is no consistent measurement of impacts on the environment, or because there is still no careful monitoring of environmental practices in the construction industry.

Zorpas (2010) presents an investigation into the need of implementation of an EMS in the SMEs. According Zorpas (2010), very small firms and also SMEs represent the economic backbone of most economies in Europe. These companies are generally mono-product or single-service, they feel a little more the economic pressure, and sold only in the local market. Sometimes they have family command and informal organization of business. For their size, they have also a "very low" level of management. They produce large amounts of waste and have employees with different nationalities, which have little access to training and are not unionized.

According Farenhof et al. (2014), despite the heterogeneity of SMEs and the lack of strategic actions within them, there is growing interest in the adoption of environmental management systems. They did a survey of the literature on environmental management systems in small and medium enterprises. Based on 27 publications on this topic, the authors investigate the main aspects that facilitate or difficult the implementation of environmental management systems in SMEs. Most of the studies are about implementation of an EMS in SMEs. The results point to some common factors. In contrast, Farenhof et al. (2014) reported a lack of knowledge about environmental impacts; low level of employee training; lack of definition of internal policies; lack of consulting and business cooperation; low level of systems integration; and high initial costs. As advantages, they perceive moral gains; cost reduction; sustainability in the medium-term; improved company image; and acquisition of new customers, highlighting the possibility of gaining competitive advantage through environmental management systems.

\section{Planning and control of production}

The process of planning and control of production can be represented in two dimensions: horizontal and vertical. In the horizontal dimension, preparation of planning process, data collection, preparation of plans, decision making and assessment of the steps taken in the process is done. In the vertical dimension, stand three levels of planning in terms of time: long, medium and short terms (Laufer \& Tucker, 1987).

According to Ballard \& Howell (1997), the Percent Plan Completed (PPC) is the main indicator of short-term planning. It is calculated by dividing the number of completed work packets by and the total number of packets scheduled for the week, according to Equation 1.

$P P C=\frac{\sum \text { Number of completed work packets }}{\text { Total of scheduled packets }} \times 100 \% \quad[$ Eq. 1]

After Ballard (2000), the PPC can be considered as a measure of the effectiveness of the production management at the operational level. According to him, if the quality requirements of the weekly plan have been met, and whether the restrictions were identified and removed at midterm in a systematic way, then a high measure of PPC indicates that the production system has high reliability. Given the uncertainty and variability that typically exists in construction, usually the average PPC in several weeks is below $100 \%$.

PPC analysis should be accompanied by the identification of the causes of non-completion of the work packets (Ballard \& Howell, 1997). This information is of great importance in the identification of key issues affecting the reliability of the production system, providing a basis for continuous improvement.

\section{Integrated management systems (IMS)}

An Integrated Management System (IMS) can be understood as a combination of processes, procedures and practices used in an organization to implement its several management policies. According to Zeng et al. (2007), was proven to be difficult to operate multiple management systems covering quality, environment, occupational health and safety and ensure alignment with organizational strategy. To investigate the status of the integrated management systems, they used a structured questionnaire. It is concluded that the main problems of the companies to operate multiple management systems include: increased complexity of internal management; low efficiency of management; and cultural incompatibility that causes some hostility from employees and increase management costs. The survey also examined the internal and external factors affecting the implementation of an IMS. Internal factors include: human resources, organizational structure, corporate culture, and perception of IMS itself. External factors are: technical 
guidance, certification bodies, stakeholders / clients and institutional environment.

In another study, Santos et al. (2011) worked with SMEs, investigating the certification of its systems for Quality Management (QMS), Environmental Management (EMS) and Occupational Health and Safety management (OHSMS). This research was based on a survey that was sent to 46 Portuguese SMEs, consisting of 20 companies (43\%) in commerce and services sector, 17 (37\%) of the industrial sector, $5(11 \%)$ of electricity / telecommunications and 4 (9\%) of the construction.

All SMEs surveyed were certified according to ISO 9001 (100\%); a quarter of the companies were certified according to ISO 14001 (26.1\%) and a few companies were certified by OHSAS 18001 (15.2\%). The results show that the main benefits that SMEs have obtained from certifications mentioned have been improving their internal organization and external image. In terms of integrated management systems (IMS), 7 of the examined SMEs indicated that the main benefits include reduced costs, increased level of employee training and better enforcement of legislation.

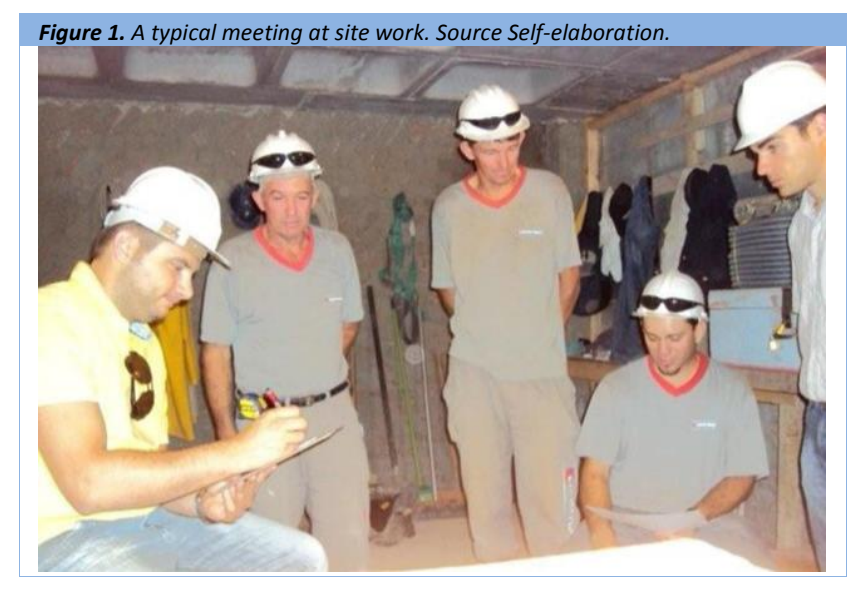

According Almeida et al. (2014), the globalization of markets has led many organizations to implement management systems as a differential against the competitors. However, with the variety of available standards, companies felt the need to integrate the management subsystems for the optimization of resources and skills. The sample examined by them consists of four organizations which have IMS with subsystems of quality management, environment management and occupational health and safety. The methodology for data collection was based on semistructured interviews with the system administrator, which was requested to analyze the whole integration process. The results suggest that integration management subsystem contributes positively on studied organizations. Some factors that administrators reported as essential for integration are the commitment of senior management and the availability of human and financial resources. Among the difficulties that organizations face they noted the absence of a prior organizational structure and changes in employee behavior.

With the integration, it is possible to see whether procedures management systems are being used only in a bureaucratic way, without adding value to the company or not. This assessment leads to greater transparency of activities and procedures in construction (Sukster, 2005). The quality movement was the first process that began to be applied in
Brazilian construction, basically due to customer pressure to get good products at lower prices. However to environment and to occupational health and safety the changes were mainly due to the pressure of legislation (Carneiro, 2005).

There are some situations in which the quality system may be benefited by the introduction of PPCP, such as scheduling of procedures and standardization activities; participation and commitment of employees and the chain of suppliers; analysis and continuous search for process improvement; use of indicators and workers training and skills development with focus on customer satisfaction (Soares, 2003).

It is important that all activities be planned and executed according to specifications. Production and other management systems must act jointly for the company to absorb the improvements (Soares, 2003). On the other hand, isolated management systems often become ineffective, difficult to manage and to achieve effective participation of people. Thus, institutions and companies have been interested in the application of integrated systems (França \& Picchi, 2007).

An Integrated Management System (IMS) that integrates quality management (based on ISO 9001 or PBQP-H), environmental management (ISO 14001) and management of occupational health and safety (OHSAS 18001) is very recent in the Brazilian construction and until now is not found in small and medium enterprises, but only some major construction (França \& Picchi, 2009; Mainardes et al, 2014.). In the study by Perez et al. (2011) on Brazilian SMEs with integrated management systems, only $11 \%$ of the companies were from the industry sector.

A study by Abreu et al. (2008) describes the behavior of the construction companies in Brazil. They have interviewed executives from 14 companies, of which most had a QMS. Among them only one was environmental system and none had the OHSMS. It has been found that many construction companies are ISO 9001 certified, and because there are demands from government and funding agencies, while there is lack of certification by the BSI OHSAS 18001 - which is a British Standard until now not absorbed in Brazil - and also by ISO14001.

ISO 14001 is a standard that is still difficult to obtain certification in this sector. However there are an evolution from $2 \%$ of the total Brazilian companies with this certification until 2006 to $16 \%$ in 2012 (Pombo \& Magrini, 2008; Lima Moura \& Silva, 2014).

According to Zeng et al. (2005), the integration of management systems is facilitated by the existence of similar parts in the rules, such as policy formulation, definition of responsibilities and training, documentation and communication.

Companies can initially have a certain resistance to the implementation and integration of these standards. However, the structure of requirements can facilitate its comprehension and application. It may be cited as major points in common (Camarini \& Picchi, 2007):

- Emphasis on continuous improvement;

- Need for demonstration of the company's ability to comply with applicable laws and regulatory requirements;

- Establishment of an organizational policy that is documented, implemented, maintained and communicated to all employees; 
- Establishment of clear goals and objectives, along with measurable indicators;

- Development of training and competence of personnel involved in activities related to the management system;

- Control of documents and data, as well as records generated;

- Monitoring and measuring of all processes.

Integration of production and other management system

The system of planning and control of production in a construction company need be oriented to prepare the structure of the quality management system (Soares, 2003). The commitment of all employees, greater participation of company directors, monitoring and data collection of all the activities taking place at the company, plus constant investment in technology are important elements for interaction between systems.

Sukster (2005) investigated the integration of quality management system and the system of planning and control of production in construction companies. He believes that the lack of integration between factors generates isolated indicators. In this sense, the company runs the risk of quality work, but later; or to meet the deadline rather than quality. Integration promotes direct and individual improvements in the development and functioning of the two systems. It was found that the incorporation of the management system with the quality of PPCP is important to the operation of the two tools (Soares, 2003).

An important point for the integration of systems is to use the weekly meetings of the PPCP to analyze also the PPC and possible problems occurred in the system of quality management, and therefore talk about the causes and provide suggestions for improvement. Another form of integration is the combined use of quality management procedures at the levels of medium and short-term. In the medium-term this occurs through the analysis of constraints, and in the short-term plan is through linking the activities scheduled for the week with instructions for process control (Sukster, 2005).

According Saurin (2002), the integration of PPCP with security management planning occurs in long, medium and shortterm. The author studied the integration between production and safety, proposing an indicator called PPS (Percentage of work packages completed with security). The PPS is a dynamic indicator, allowing the identification of deficiencies in security planning that can lead to accidents and was developed based on the indicator for production control (PPC), in order to assess the reliability of the safety planning (Saurin, 2002).

According Saurin et al. (2002), a research conducted in the United States concluded that among several preventive measures that have been used by the construction industry, the planning of construction safety before starting the work and before beginning of each activity is one of the most effective ways to achieve the goal of "zero accidents". Still, the integration of security requirements with PPCP has been relatively little studied, except Carneiro (2005) and Kartam (1997).

\section{Barriers to systems integration}

The complexity of the processes that occur in the process of system integration can impose barriers to the development of management activities in construction companies.

May be observed a growing concern with environmental issues in Brazil and also in other countries. In construction it can be said that little was further developed, as there are few certified by ISO 14001 . To facilitate the integration of management systems companies it is necessary that the regulations and specifications be adjusted to promote equivalence of requirements management systems (Carneiro, 2005). After Sukster (2005), the main drawbacks noted that difficult the full integration between systems are lack of cooperation, training and motivation of all employees involved in the processes.

In a case study on the company Camargo Correa - a great Brazilian firm and which has a IMS -, some difficulties were encountered, including the coordination of procedures of different areas of the company and organization of specific training which be appropriate to each employee (França \& Picchi, 2007).

Another factor that may hinder the integration of systems integration is the integration of small site works that often do not communicate the improvements obtained in a building to other works of the company.

\section{Research procedures}

The study was conducted in two stages, which mainly consist of: (i) diagnosis, definition of the proposed approach and proposal for integration, and (ii) application and analysis of the results, as shown in Table 1.

\begin{tabular}{l|l} 
Table 1. Outline of the research. Self-Elaboration \\
\hline Phase & Stages \\
\hline \multirow{2}{*}{ (i) diagnosis } & Diagnosis and definition of the approach \\
\cline { 2 - 2 } & Proposal for systems integration \\
\hline \multirow{2}{*}{$\begin{array}{l}\text { (ii) application } \\
\text { and analysis }\end{array}$} & Application and analysis of integrated system \\
\cline { 2 - 2 } & Integration of documents \\
\cline { 2 - 2 } & Analysis of system implementation \\
\hline
\end{tabular}

\section{Diagnosis and definition of approach}

a) Identification of the company and the observed work: The company has 30 years of activity in the housing sector. It had implemented the Brazilian certification Program of Quality and Productivity of Habitat (PBQP-H) at its level A. After to fulfill some additional requirements it has also been certified by the NBR ISO9001 in 2005. The certification by ISO9001 brought some improvements in organization and management of the client, but few advances in productivity.

This construction has a own team involving engineering, procurement and financial management. In the production sector this enterprise mix own workers and third parties workers. The number of employees is 90 people in total.

The company implemented an Occupational Health and Safety Control Program in 2008, which is based on the Brazilian regulatory standards. More recently, with increasing demand and decreasing the delivery of the works, the 
company launched a PPCP system, in order to gain more control, better compliance with deadlines and reduce losses.

The company invests in the professional qualifications of their employees through courses and conferences in various areas of knowledge, from training of secondary personal to specialization of the engineering team. To achieve the objectives of the study were monitored three housing siteworks (calls as projects A, B and C), all located in the city of Bento Gonçalves (southern Brazil). The works were studied at different stages of progress. Therefore, it was possible to control all flows of materials and services on a project or another.

Project $A$ was in the first stage of construction, while the $B$ was in an intermediate stage, and the project $C$ was in final stage of construction. Note that they have similar sizes and quality standards. In all projects, information was obtained in order to make a diagnosis of the condition before, during and after the implementation of the integrated management system is proposed.

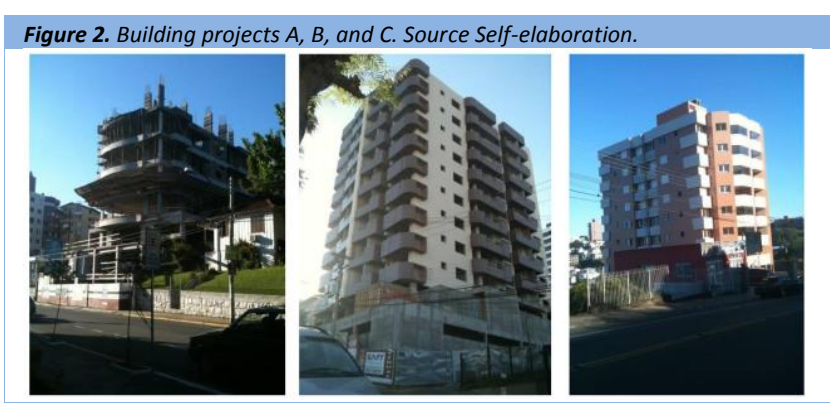

Project $A$ is located in a prime residential area of the city. The building has approximately $7,300 \mathrm{~m}^{2}$ and construction costs of about $\$ 8.8$ million. The foundations are shallow (concrete bases), and the structure is on reinforced concrete. The exterior and interior walls are built with solid masonry bricks. At the time the study began had made embankments of the land, and early parts of concrete structure. Activities observed were masonry and structure.

Project B is located near the city center. It has a floor area of approximately $5,800 \mathrm{~m}^{2}$ and corresponds to a value of $\$ 6.7$ million. At the start of the investigations were occurring activities of masonry, installations and wall coverings, which were observed.

Project $C$ is also located in a residential area of high level, and has a floor area of approximately $6,200 \mathrm{~m}^{2}$. The construction budget for this project is around to $\$ 6.8$ million. This project was in the final stages of construction when the study began. Activities observed were laying ceramic tile, glass and paint.

b) Initial Study - exploration and diagnosis: At this stage an internal audit was conducted with application of 27 questionnaires to employees (from staff to managerial workers) to get an overview of the system. Issues covered included document control, commitment of top management (as perceived by employees), knowledge of employees on quality policies and working conditions in all sectors of the company. The questions were answered as attending / not attending.

After a meeting of critical analysis with top managers and the quality committee of the company was held. It was developed a diagnosis of management systems employed by the company at this time. As for the PPCP, it was made an analysis of existing documents, inspection at work sites and accompanying of regular planning meetings. After this the management system implemented in the enterprise was analyzed, in view of the integration with other management systems and to identify the changes needed to make the integration.

It was inspected existing documentation for quality management system, especially H-PBQP Company ISO 9001 certification documents and analyzed. The next analysis was about the QMS of the company, with suggestions for improvement and testing of the feasibility of integration with other systems and with the PPCP was performed. We also conducted an analysis of the environmental aspects. We reviewed the documents, construction practices and the ability to comply with environmental laws.

\section{Integration of management systems}

Based on the data collected and the analysis of the general situation of the company, some actions towards integrating systems of management were proposed. PPCP is a management system that works on the vertical level in the timeline, this is, deal with long, medium and short terms. From this perspective, we have proposed the inclusion of the other MS on the same timeline.

The integration of existing documents is of great importance for the integration of the MS. For example, the company must develop a single manual with all information management systems for quality, environment and occupational health and safety. In summary, we have proposed the integration of planning systems to long, medium and short terms as well as the application of performance indicators in the short-term.

In the horizontal dimension, the preparation of the planning process, data collection, preparation of plans, dissemination of information and actions, as well as being assessed the planning process itself is done. In the vertical dimension, the activities are divided hierarchically into levels of long, medium and short-term, as follows:

a) Integration of the systems in the long-run level: For integration in the long-run level, the activities related to the main stages of construction (or macro-activities, such as "structure") that were taken from the long-term programming are considered. Requirements for quality, environment and safety were considered, which were included in the quality documentation of the company. This level of planning is assigned to engineering department.

b) Integration of the systems in medium-term level: For the integration of the systems in the medium-term level, we consider the activities established in the medium-term planning. We collected the requirements for quality, environment and safety which are part of company documentation. This level of planning is also the responsibility of the engineering department. This level is important for the integration of the levels of short and long terms. Also on this level are scheduled some purchases, which also must meet the requirements of quality, environment and safety.

c) Integration of systems in short-term level: For systems integration at the level of short-term we consider the weekly 
activities defined in the PPCP, which are obtained from shortterm scheduling, and were integrated with the plans of control of quality, environment and safety requirements. This level of planning is discussed in the weekly meetings of PPCP.

The use of some indicators was proposed as based on the percentages of packages completed with quality, safety and environmental best practices (called, respectively, as PPQ, PPS and PPE). These indicators are measured for the same activities that were included in the production plan in the short-term and are detailed in sequence.

The Percent Plan completed with Quality (PPQ) indicates the percentage of work plans developed with expected quality. It is considered that a package of work is done with quality, if all specified quality requirements for each activity in the control sheet of short-term activities are respected. Equation 2 (which is based on Equation 1) is used to calculate the PPQ.

$P P Q=\frac{\text { Number of completed work packets with quality }}{\text { Total of scheduled packets }} \times 100 \% \quad$ [Eq. 2]

$P P S=\frac{\text { Number of completed work packets with safety }}{\text { Total of scheduled packets }} \times 100 \% \quad$ [Eq. 3]

$P P E=\frac{\text { Number of compl. packets with environmental req. }}{\text { Total of scheduled packets }} \times 100 \%$ [Eq. 4]

The Percent Plan completed with Security (PPS) indicates the percentage of complete packages with occupational health and safety (after Saurin, 2002; Saurin et al., 2002). It is considered a package of work done safely if all health and safety requirements for packages specified in the short-term sheet are respected. Equation 3 is used to calculate the PPS.

Finally, the Percent Plan completed with Environmental requirements (PPE) indicates the percentage of work packages made with attention to environmental requirements. It is considered a package of work with environmental requirements when all environmental requirements for activities specified in the short-term sheet are met. Equation 4 is used to calculate the PPA.

\section{Application and results}

\section{Implementation of the integrated management system}

They were accompanied the works presented above (projects A, B and C), in order to measure and analyze the indicators proposed. The integrated system was implemented entirely in Project B and partially in the other two. Systems integration occurred in two stages:

- On medium and long-term plans the integration occurred through the documentation, ie, through the Work Instructions and Quality Requirements;

- In the short-term plan, the execution was carried out through the short-term planning.

Therefore, one can obtain quantitative measures of the management systems with PPQ, PPS and PPE indicators, which are compared with PPC. For the implementation of the new indicators, we propose a planning form which includes the measurement of these new aspects for the same activities that are controlled in PPCP at the short-term level. In short, systems, plans and indicators of the integrated system are presented in Table 2.

\begin{tabular}{l|l|l|l}
\multicolumn{4}{l}{ Table 2. Identification of the systems, plans, and indicators. Self-Elaboration } \\
\hline $\begin{array}{l}\text { Management } \\
\text { system }\end{array}$ & Management & Planning & Measurement \\
\hline Production & PMS & PPCP & PPC \\
\hline Quality & QMS & QPC & PPQ \\
\hline $\begin{array}{l}\text { Occupational } \\
\text { health and safety }\end{array}$ & OHSMS & OHSPC & PPS \\
\hline Environment & EMS & EPC & PPE \\
\hline
\end{tabular}

\section{Document integration}

According to initial surveys, it was verified the integration of health and safety issues in the documentation of quality system. It was also noted that there is no formal environment system in this enterprise. After making this initial analysis, we suggest some measures for the implementation of the EMS. Some results about document integration related to EMS are shown:

a) Quality Policy of the company: The company studied had its quality policy covering only aspects of quality, with the following wording: "Acting in the construction of buildings, meeting the expectations and needs of our customers and continually improving our processes." After meets with managers and the engineering team and to check the guidelines of the company the quality policy was changed to: "Acting in the construction of buildings, meeting the expectations and needs of our internal and external customers, and continuous improvement of our processes, respecting the aspects of quality, environment and occupational health and safety"

b) Work Instructions (WI): We observed that the WI used by the company, in addition to the description of how to run the service with quality standards set by the company, also had record the relevant safety requirements. So were included environmental issues in WI.

c) Quality Requirements ( $Q R$ ): All requirements related to safety and environment aspects were included on Quality Requirements records. It was found that may have to be implemented new quality requirements. This will happen gradually, when the company needs registration, by applying the principles of continuous process improvement. It is a major part of the QR integrating documents such as Document control, Treatment of non-conformities, Records and Audits.

d) Quality Manual: The Quality Manual, in addition to quality control, did was involved with security issues. Then it was incorporated in the Quality Manual a new chapter with regard to environmental issues.

\section{Implementation of management systems}

The systems were implemented in the following manner.

a) Addition of QPC, OHSPC and EPC in medium and long-term plans through the integration of documents; 
b) Addition of QPC, OHSPC and EPC in the short-term plan: Integration of the activities planning of PPCP in the shortterm with the aspects of quality, safety and environment control; Measurement of short-term indicators - PPC, PPQ, PPS and PPE; Analysis of the evolution of the integration of short-term indicators.

In the sequence the management systems were integrated with PPCP. In this stage were included documentation about and planning and control systems proposed (QPC, OHSPC and EPC), and included the implementation of short-term indicators (PPQ, PPS and PPE). At the conclusion of this stage, the results of these indicators were compared with PPC.

The results obtained are:

a) Implementation on medium and long-term plans: Integration of PPCP with QPC, OHSPC and EPC in medium and long-term plans occurred in a documental way. In this case, safety and environmental requirements were implemented in activities scheduled in medium and long-term plans of through WI. Document control, treatment of nonconformities, audit and records are controlled by the QR.

b) Application in short-term plan: Control activities to quality, safety and environment requirements were added to each activity present in the short-term planning, scheduled weekly. So, on short-term activities plan were added three control schemes, one for each new requirement and the respective percentages are measured.

Table 3 shows the results of measuring PPC, PPQ, PPS and PPE. These measurements were obtained from observations of the activities in the projects within four weeks.

\begin{tabular}{l|l|l|l|l|l}
\multicolumn{6}{l}{ Table 3. Results of short-term indicators. Source: Self-Elaboration 2014.} \\
\hline Week & Period & PPC & PPQ & PPS & PPE \\
\hline 1 & 31 jan - 4 feb. & 63 & 83 & 85 & 75 \\
\hline 2 & $7-11$ feb. & 79 & 92 & 70 & 75 \\
\hline 3 & $14-18$ feb. & 72 & 90 & 70 & 75 \\
\hline 4 & $21-25$ feb. & 73 & 88 & 75 & 75 \\
\hline
\end{tabular}

It was observed that measured indicators apparently do not interfere with each other. From the results, the company began to take control measures nonconformities discovered in three new areas (the company already had this procedure for nonconformities of production). Figure 3 shows the comparison of the weekly evolution of the integration of the PPC, PPQ, PPS, and PPE indicators.

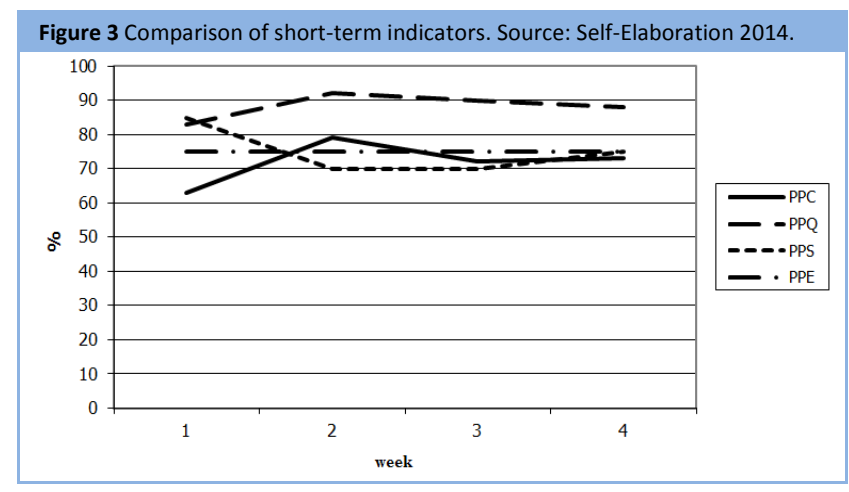

The graph shows a comparison between the measured indicators. The new indicators have a little effect with each other, but all are related with the results of PPC. With the treatment of non-conformities found in the three new indicators, probably PPC indicator will reaches more successful numbers. One item to note is that it became clearer the lack of compliance with the activities stipulated in the short-term plan and, therefore, the continuous improvement process adopted by the company is provided.

In the productive sector, first there was some resistance from site workers on the implementation of the indicators system, with the justification that it may compromise your productivity. This problem was solved with the first measurements of the tasks performed, which showed, in some cases, increased productivity, which seemingly are related with a better organization and cleanliness in the workplace and by the effective use of short-term plan which served as an objective to be achieved by the teams.

We could verify - based on the observation of researchers and questionnaire results - that the application of the system of indicators made an increased engagement of the employees participating in the process, from the management level / firm directors to site workers.

Discussion

\section{Integration evaluation}

To evaluate the integrated management system, we apply new questionnaires, aimed at verifying the application of certain requirements of ISO 9001, ISO 14001 and OHSAS 18001. These questionnaires follow the model already used and ware applied to the same people, but now some specific questions were included which are related with each certification, asking about quality, environment and labor. Some results can be drawn:

a) It can be said about the PPCP that there were systemic changes in management, since it was found that some aspects were neglected due to the lack of transparency in the process. After the application of QPC, OHSPC and EPC and integration of these systems with the PPCP, those aspects that were neglected for lack of knowledge were better observed and were treated the nonconformities, creating a broader framework for continuous process improvement system;

b) It was found that the QMS meets the requirements of ISO 9001 and PBQP-H, but the system did not record the proper execution of the improvements made at work. There were quality control in the daily work at the company, but these controls were carried out informally, and several errors reappeared, since there was no effective treatment for noncompliance. With the implementation of the QPC, there was a significant improvement in the processes related to the quality of the final product. Among other improvements, a greater commitment of the teams, better management of non-conformities, extending the continuous improvement process, reducing waste of materials and reduced re-work done due to the low quality were observed;

c) In the area of occupational health and safety system, early research also showed that there was an OHSMS formally implemented. With the revaluation of the system after the application of IMS, we observed that the OHSMS had created a good structure, and the results were satisfactory with 
respect to safety itself. With the implementation and measuring of PPS, we found that the indicator had strong impact on PPC due to the lack of management of the occupation of each employee in the company. Better planning in the provision of work equipment has yielded positive results in the productivity of the company reduced losses from idle employees that previously existed. It was also observed that there was a reduction in the number of accidents or near accidents due to greater use of protective equipment and adherence to safety regulations;

d) For the environment system was found that after the application of IMS some requirements of the NBR ISO 14001 began to be implemented in the company through $\mathrm{WI}$ and QR. The implementation of the EPC has brought improvements to the company with respect to reduction in material waste, now partly controlled by the PPE indicator. The difficulty has yet been observed is that the company has many of the services performed by third parties, which don't have the same knowledge and commitment of own employees. The waste management in the company seems to be difficult to understand by third parties providing not continuous services and is a complicating factor for hiring them, due to the expansion of costs, but also because there is no supervision and qualified personnel to manage losses by third parties.

\section{Findings}

We proposed an IMS with the integration of quality, safety, environment and production systems, thought integration of existing documents and integration of these systems. The system was applied to some site works of a small construction company, with a review of the results, based, inter alia, as was verified in the questionnaires. There are some points that can be highlighted:

- Application of IMS brought improvements to the company, in terms of organization and productivity;

- Losses are detected more easily and the company made easier the treatment of non-conformities;

- Work teams have better understand the global quality policy of the company and that it depends on compliance with the requirements of quality, safety and environment, by everyone.

Given these observations, we can say that the IMS proposed and implemented has improved the company in order to reduce losses and also the formation of a new professional, skillful, able to see and appreciate their daily efforts in production and increasing awareness regarding issues of quality, safety and environment. In contrast we have other considerations:

- Initial difficulty verified in communicating with production staff;

- Lack of qualified personnel for the implementation of IMS in the company staff;

- In relation to environmental issues, we found that the implementation of the EMS was efficient, but is hampered by several factors, including a lack of qualified personnel, lack of oversight in the legislation itself and the lack of awareness of the problem in all areas (management, government, and others).

As limitations of the work, one can cite that only one company was studied for a short period of time. Local differences in the companies or different teams within the same company can change the results.
In the end, despite the difficulties, partly because of the size of the company and the conservative culture of the workforce of the construction, the proposed work has brought several changes - perceived through the positions of employees (expressed in the questionnaires) and observation of the researchers - beneficial to the company, such as greater transparency in the process, greater stakeholder participation and therefore an overall improvement in productivity and a real concern about environmental aspects in the company, among other changes.

Based on the results of this study, future research should include the development of methods of implementation of integrated management systems for different companies to allow the results to be generalized; extend the studies on the implementation of sustainable technologies for small and medium enterprises, with measurement indicators proposed (PPQ, PPS, PPE); and investigate the impacts of the use of indicators from different perspectives / characters, such as owners, director, employees, public sector and consumers / customers.

\section{Acknowledgments}

The authors thank to CNPq for financial support in the form of scholarship and productivity of the second author and to Banco Santander do Brasil for the grant of the first author's master. Finally, we also thank UNISINOS, which featured research conditions.

\section{References}

Abreu, L. D., Idrogo, A. A. A., Saraiva, O. F. C., Costa, A. R. T., \& Fonseca, R. B. (2008). Sistemas de Gestão (qualidade, ambiental, saúde e segurança) na Construção Civil em Empresas do Estado do Espírito Santo. XXVIII ENEGEP (Encontro Nacional de Engenharia de Produção). Rio de Janeiro, Brasil.

Almeida, J., Domingues, P., Sampaio, P. (2014, Jan 08). Different perspectives on management systems integration. Total Quality Management \& Business Excellence, 25(3-4), 338351.

ABNT NBR ISO 14001 (2004). Associação Brasileira de Normas Técnicas. Sistemas de gestão ambiental: Especificações e diretrizes para uso. Associação Brasileira de Normas Técnicas: Rio de Janeiro, Brasil.

Associação Brasileira de Normas Técnicas - ABNT (2008). NBR ISO 9001: Sistemas de gestão da qualidade - Requisitos. Rio de Janeiro, Brasil: ABNT.

Ballard, G. (2000). The Last Planner System of Production Control, Thesis PhD en Ingeniería Civil, Universidad de Birmingham [Thesis in English].

Ballard, G., Howell, G. (1997). Implementing Lean Construction: improving downstream performance. Lean Construction, 111-125.

Brasil. Ministério das Cidades Programa Brasileiro de Qualidade e Produtividade no Habitat (PBQP-H). Portaria no 134, de 18 de dezembro de 1998. MinCidades, Brasília, Brasil. (1998). Retrieved from: <http://www.cidades.gov.br/pbqp-h/>. [visited 15.10.2014]

BSI OHSAS 18001 (1999). British Standards Institution. Occupational health and safety management systems - specifications. British Standards Institution: London. 
Camarini, G., Picchi, F. A. (2007). Sistema de Gestão Integrada (SGI): estudo de caso uma empresa construtora de grande porte. Anales del V SIBRAGEC - Simpósio Brasileiro de Gestão e Economia da Construção. Campinas, Brasil.

Carneiro, S. Q. (2005). Contribuição para a Integração dos Sistemas de Gestão Ambiental, de Segurança e Saúde no Trabalho, e da Qualidade, em Pequenas e Médias Empresas da Construção Civil, Thesis Master Ingeniería Ambiental Urbana, Universidade Federal da Bahia (UFBA), Salvador, Brasil. [Thesis in Portugues].

Farenhof, H. A., Vignochi, L., Selig, P. M. \& Lezana, Á. G. R., Campos, L. (2014, July 1). Environmental Management Systems in Small and Medium-sized Enterprises: An Analysis and Systematic Review. Journal of Cleaner Production, 7, 4453.

França, N. P., Picchi, F. A. (2007). Sistemas integrados de gestão: Qualidade, meio ambiente, segurança e saúde em empresas construtoras brasileiras. Anales del V SIBRAGEC - Simpósio Brasileiro de Gestão e Economia da Construção. Campinas, Brasil.

França, N. P., Picchi, F. A. (2009). Sistema Integrado de Gestão: Percepção dos colaboradores de empresa construtora de edifícios. Anales del VI SIBRAGEC - Simpósio Brasileiro de Gestão e Economia da Construção. João Pessoa, Brasil.

Garengo, P., Biazzo, S. (2013). From ISO quality standards to an integrated management system: An implementation process in SME. Total Quality Management \& Business Excellence, 24(3-4), 310-335.

Kartam, N. (1997). Integrating safety and health performance into construction CPM. Journal of Construction Engineering and Management, 123(2), 121-126.

Laufer, A., Tucker, R. L. (1987). Is Construction Planning Really Doing its Job? A critical examination of focus, role and process. Construction Management and Economics, 5(5), 243-266.

Lima Moura, L., Silva, R. F. (2014). Difusão da ISO 14001 no brasil: análise comparativa dos estados e dos setores de atuação. Revista Gestão Industrial, 9(4), 972-984.

Maekawa, R., Carvalho, M. M. D., \& Oliveira, O. J. D. (2013, Nov 5). Study on ISO 9001 certification in Brazil: mapping the motivations, benefits, and difficulties. Gestão \& Produção, 20(4), 762-780.

Mainardes, C. W., Krainer, J. A., Neto, A. I., Romano, C. A., \& Silva, H. D. F. N. (2013). Análise dos impactos da utilização do erp nos processos organizacionais de empresas de construção civil. Revista Engenharia e Construção Civil, 1(1), 74-89.

Moura, C. B., Formoso, C. T. (2009). Análise quantitativa de indicadores de planejamento e controle da produção: impactos do Sistema Last Planner e fatores que afetam a sua eficácia. Ambiente Construído, 9(3), 57-74.

Neiva Neto, R., Ruschel, R. C., \& Picchi, F. A. (2013). Avaliação de ferramentas de tecnologia da informação na construção com funcionalidades móveis compatíveis aos itens da NBR ISO 9001: 2008. Revista Eletrônica de Engenharia Civil, 6(1), 16-23.
Perez, G., Berlezzi, F. L. C., da Silva, M. M., \& de Souza, M. A. (2011). Fatores que determinam a escolha de sistemas integrados de gestão (erp) em pequenas e médias Empresas: um estudo usando análise fatorial. Revista da Micro e Pequena Empresa, 3(3), 36-53.

Pombo, F. R., Magrini, A. (2008). Panorama de aplicação da norma ISO 14001 no Brasil. Gestão \& Produção, 15(1),1-10.

Santos, G., Barros, S., Mendes, F. \& Lopes, N. (2013). The main benefits associated with health and safety management systems certification in Portuguese small and medium enterprises post quality management system certification. Safety Science, 51(1), 29-36.

Santos, G., Mendes, F., \& Barbosa, J. (2011). Certification and integration of management systems: the experience of Portuguese small and medium enterprises. Journal of Cleaner Production, 19(17), 1965-1974.

Saurin, T. A. (2002). Segurança e Produção: Um modelo para o planejamento e controle integrado. Thesis (Doctorado en Ingeniería de Producción), Universidade Federal do Rio Grande do Sul (UFRGS), Porto Alegre, Brasil. [Thesis in Portugues].

Saurin, T. A., Formoso, C. T., \& Guimarães, L. B. M. (2002). Segurança e produção: Um modelo para o planejamento e controle integrado. Revista Produção, 12 (1), 60-71.

Soares, A. C. (2003). Diretrizes para a Manutenção e o Aperfeiçoamento do Processo de Planejamento e Controle da Produção em Empresas Construtoras, Thesis Master en Ingeniería Civil, Universidade Federal do Rio Grande do Sul (UFRGS), Porto Alegre, Brasil. [Thesis in Portugues]

Sukster, R. A. (2005). Integração entre o Sistema de Gestão na Qualidade e o Planejamento e Controle da Produção em Empresas Construtoras, Thesis Master Ingeniería Civil, Universidade Federal do Rio Grande do Sul (UFRGS), Porto Alegre, Brasil. [Thesis en Portugues].

Zeng, S. X., Shi, J. J., \& Lou, G. X. (2007). A synergetic model for implementing an integrated management system: an empirical study in China. Journal of Cleaner Production, 15(18), 1760-1767.

Zeng, S. X., Tian, P., \& Shi, J. J. (2005). Implementing integration of ISO 9001 and ISO 14001 for construction. Managerial Auditing Journal, 20 (4), 394-407.

Zorpas, A. (2010). Environmental management systems as sustainable tools in the way of life for the SMEs and VSMEs. Bioresource Technology, 101(6), 1544-1557. 